\title{
Perbedaan Struktur Otak dan Perilaku Belajar Antara Pria dan Wanita; Eksplanasi dalam Sudut Pandang Neuro Sains dan Filsafat
}

\author{
M. Syahruddin Amin \\ Prodi Pendidikan Biologi, Universitas Hamzanwadi, Nusa Tenggara Barat, Indonesia \\ e-mail: muhammad_syahruddinamin@yahoo.com
}

\begin{abstract}
Human beings as agents of change and well-being on Earth was created by God in two types of different biological potential. The potential is equipped to carry out their mandate. This potential will be optimized through the correct process in accordance with the characteristics of each type of sexual potency. This qualitative studies, research library, is aimed to providing an explanatory link between gender, brain structure, and learning behavior. Brain structures of men and women have differences in the anatomical aspects, physical (size), and a way of thinking, including learning. Teach boys more appropriate to use a pattern that puts the visuospatial, challenging, and rich in hands-on activities. While teach women would be more effective to use a pattern that emphasizes language and communication abilities such as reading, writing, lectures, casual discussions, collaboration, and presentation. In education, differences in the way and learning styles of men and women can be facilitated with several options for how such multiple female teachers at the level of primary education, the separation of classes between men and women, applying combinative methods of teaching in heterogeneous class
\end{abstract}

Keywords: gender men and women brain learning behavior

\section{Pendahuluan}

Kita semua bersepakat bahwa manusia adalah makhluk yang diturunkan oleh Tuhan untuk mengelola dan membawa kemaslahatan di Bumi. Manusia merupakan makhluk yang kompleks dengan berbagai dimensinya. Dimensi umum yang familiar kita dengar atau baca yaitu manusia adalah makhluk biologis, makhluk individu, makhluk sosial, dan makhluk spiritual. Dalam hal ini, Socrates berpandangan manusia adalah zoon politicon, hewan yang bermasyarakat, sedangkan Mex menyebut manusia dengan das kranke, hewan yang selalu merasa sakit serta gelisah. Seiring perkembangan ilmu, keilmuan modern memunculkan beberapa istilah terkait pemahaman tentang hakikat manusia: homo sapiens (makhluk cerdas dan berbudi), homo faber (makhluk yang mampu membuat berbagai peralatan untuk memenuhi kebutuhan hidupnya), homo economicus (makhluk yang bersifat ekonomi), homo laquen (makhluk yang memiliki bahasa untuk menyampaikan pikiran), dan homo erectus (makhluk yang berdiri tegak).Secara biologis, manusia adalah sekumpulan sel hidup yang menyatu dalam struktur jaringan yang secara bersama membentuk sebuah organ, sistem organ, hingga menjadi organisme. Manusia adalah makhluk yang lahir, tumbuh dan berkembang, dan mati. la juga makhluk yang butuh makan, minum, dan udara (bernafas).

Manusia oleh Tuhan secara biologis diciptakan dalam dua tipe, yang kita istilahkan dengan jenis kelamin, yaitu laki-laki dan perempuan, yang tumbuh dan berkembang dengan karateristik biologisnya masing-masing. Dalam fisik manusia, terintegrasi didalamnya beragam potensi yang hakikatnya adalah bekal bagi manusia untuk bisa bertahan dalam tugasnya mengelola Bumi. Bekal tersebut termanifestasi dalam struktur anatomi dan fisiologi tubuhnya, ia hanya perlu memfungsikannya secara optimal melalui proses belajar (pendidikan). Secara filosofis, hakikat pendidikan adalah membentuk manusia sempurna atau insan kamil dimana manusia yang berkembang seluruh potensi atau kecerdasannya, baik potensi jasmani, ruhani maupun akal (Tafsir, 2006). Pendidikan merupakan bagian integral dalam proses evolusi manusia untuk mempertahankan eksistensinya dan menjalankan amanahnya. Pendidikan adalah proses memanusiakan manusia agar mampu menjalani hidup sesuai dengan hakikat dirinya sebagai manusia. Harus dipahami, bahwa perbedaan tipe biologis mengindikasikan adanya perbedaan potensi utama dalam diri individu yang berbeda tersebut. Lingkungan sosial 
mempunyai andil dalam pembentukan moral dan karakter peserta didik. Pembentukan karakter moral dipengaruhi oleh interaksi yang bersifat herediter dengan faktor lingkungan, pertama, peranan sekolah dalam pembangunan manusia berkarakter moral (Silberman, 2005). Dalam dinamika sosial dan pendidikan, terdapat banyak fenomena yang terabaikan karena dipahami sebagai suatu hal yang normal atau umum terjadi, misalkan laki-laki lebih agresif sementara perempuan lebih pemalu, perempuan cerewet laki-laki lebih pendiam, dan sebagainya. Beberapa contoh fenomena dalam pendidikan seperti anak/siswa nakal yang didominasi lakilaki, pencapaian belajar siswa laki-laki yang umumnya lebih rendah dari siswa perempuan, perbedaan cara belajar siswa dan siswi, perbedaan cara mengajar guru laki dan perempuan, guru yang menghukum siswa, siswa laki-laki lebih sulit diatur ketimbang siswa perempuan, dan lainnya. Dalam sudut pandang neurosains, hal itu merupakan manifestasi dari adanya perbedaan pada otak mereka. Hal ini penting untuk dipahami terutama oleh guru dan orang tua sebagai pendidik utama seorang anak. Artikel ini mencoba menghadirkan sebuah eksplanasi tentang hubungan antara anatomi otak, jenis kelamin, dan perilaku individu terkait proses belajar dari sudut neurosains dan filsafat. Hal ini sangat penting karena pemahaman yang benar tentang perilaku belajar anak/siswa, yang ternyata terkait dengan struktur otaknya tentu akan memudahkan guru dalam penentuan treatment yang sesuai bagi proses belajar siswa, mengurangi potensi adanya pemberian perlakuan (hukuman) terhadap siswa, dan memberikan kenyamanan bagi siswa untuk mewujudkan pencapaian terbaiknya.

\section{Metode}

Dalam studi kualitatif ini, penulis mencoba menghadirkan konstruksi ilmiah dari beberapa fakta yang saling berkaitan. Dalam hal ini penulis menggunakan studi kepustakaan (library research). Proses dalam studi ini dilaksanakan melalui penelaahan terhadap buku, literatur, dan artikel ilmiah tentang gender, anatomi otak, dan pola belajar. Data dan temuan dari berbagai hasil penelitian serta telaah pustaka merupakan data dalam studi ini. Data tersebut selanjutnya diolah dan di sintesis hingga akhirnya menjadi sebuah kerangka informasi yang terstruktur secara ilmiah.

\section{Hasil dan Pembahsan}

Otak merupakan organ kecil yang tersimpan didalam batok kepala yang merupakan pusat sistem syaraf dan berfungsi sebagai pusat kendali dan koordinasi seluruh aktifitas biologis, fisik, dan sosial dari seluruh tubuh. Batok kepala manusia rata-rata mampu menampung volume sekitar $1700 \mathrm{ml}$ yang berisi $1400 \mathrm{ml}(80 \%)$ otak, $150 \mathrm{ml}(10 \%)$ darah, dan $150 \mathrm{ml}(10 \%)$ cairan otak. Manusia terlahir dengan struktur otak yang sempurna dengan berat sekitar 1300-1400 gram (2\% berat tubuh). Otak merupakan sumber dari seluruh pemikiran, perasaan, keinginan, dan juga merupakan penjaga memori kita (Hewitt, Lyons,et al, 2006: 430). Didalam otak terdapat 100 miliar sel neuron dan 1 trilyun sel neuroglia. Setiap neuron mampu membangun 10.000 cabang dendrit bahkan bisa mencapai 100.000 , sehingga akan terbentuk 1000 trilyun sinapsis (koneksi komunikasi) (Rakhmat, 2005). Secara anatomis, otak terbagi menjadi 3 bagian utama yaitu: otak besar (cerebrum), otak kecil (cerebellum), dan batang otak (brainstem).

Otak menangkap semua rangsangan untuk dipahami (dipersepsi) melalui kerja sel saraf, sirkuit saraf, dan nemotransmitter (Wathon, 2016). Otak besar (cerebrum) merupakan bagian terbesar $( \pm 80 \%)$ dari berat otak. Otak besar merupakan pusat aktifitas mental seperti memori (ingatan), kepandaian (inteligensia), dan juga kesadaran dan pertimbangan. Keberadaannya memungkinkan individu untuk berpikir, berbicara, mengingat, dan mengendalikan pikiran. Otak ini pun memiliki peran yang besar dalam proses belajar seseorang. Selain itu, tingkat kecerdasan individu juga dibentuk di otak besar. Bongkahan cerebrum terbagi menjadi dua belahan (hemisfer) yaitu kiri dan kanan oleh alur fissura longitudinal. Setiap hemisfer memiliki fungsi yang berbeda. Otak kiri, dikenal sebagai otak rasional bekerja dalam pola yang linier, sekuensial, mengurusi hal-hal yang terkait logika-rasio, kata dan bahasa, dan matematik. Sebaliknya otak kanan atau otak irasional bekerja dengan pola yang tidak teratur, berkaitan dengan kreativitas, seni, desain, musik, warna dll. Selain itu belahan otak ini berfungsi untuk kontrol dan koordinasi bagian tubuh secara bersilangan. Kedua belahan otak ini terhubung oleh sebuah struktur jaringan syaraf yang disebut corpus callosum. Cerebrum terbagi dalam beberapa bagian (lobus) dengan fungsi khasnya masing-masing, yaitu: (a) Lobus frontal; kegiatan berpikir, perencanaan, dan penyusunan konsep, (b) Lobus temporal; bertanggung 
jawab pada persepsi suara dan bunyi, (c) Lobus perietal; bertanggung jawab pada kegiatan berpikir, terutama pengaturan memori Lobus occipital; mengatur fungsi penglihatan (Pasiak, 2005: 68). Keseluruhan bagian otak terbungkus oleh selaput yang dinamakan cortex cerebri (kulit otak). Struktur ini melapisi seluruh permukaan cerebrum hingga pada lekukan terdalam sekalipun. Lapisan ini memiliki ketebalan yang bervariasi antara $1,5 \mathrm{~mm}-4,5 \mathrm{~mm}$, rata-rata 2,5 $\mathrm{mm}$ (lobus frontal), paling tebal 4,5 mm (area motorik), dan paling tipis $1,5 \mathrm{~mm}-2,2 \mathrm{~mm}$ (area visual). Jumlah sel syaraf pembentuknya sekitar 2,6 x 109 sel neuron. Struktur ini terlihat "tak beraturan" berupa lekukan (konvolusi) yang terdiri atas cekungan (sulcus) dan tonjolan (gyrus). Fungsi utama kulit otak yaitu fungsi sensorik, asosiasi, dan motorik. Melalui instrumen Positron Emission Tomography (PET) diketahui bahwa terdapat enam sistem otak (brain system) yang secara terpadu meregulasi semua perilaku manusia. Keenam sistem otak tersebut adalah cortex prefrontalis, sistem limbik, gyros cingulatus, ganglia basalis, lobus temporalis, dan cerebellum. Keenam sistem otak tersebut mempunyai peranan penting dalam pengaturan kognisi, afeksi, dan psikomotorik, termasuk IQ, EQ, dan SQ (Suyadi, 2012).

Otak kecil (cerebellum) terletak dibagian belakang kepala, dibawah lobus occipital dekat dengan ujung leher bagian atas. la terhubung ke otak melalui pedunculus cerebri. Cerebellum bertanggung jawab dalam proses koordinasi dan keseimbangan. Secara lebih detil Rohkamm (2004: 54) menjelaskan struktur dan fungsi otak kecil terbagi pada tiga spesifikasi, yaitu vestibulocerebellum (anrcheocerebellum), terdiri atas flocculonodular lobe dan lingula, bertanggung jawab untuk mengontrol keseimbangan, otot aksial dan proksimal, irama pernafasan, pergerakan kepala dan mata (stabilisasi pandangan). Kedua, spinocerebellum (paleocerebellum); berfungsi dalam mengontrol otot-otot yang berkaitan dengan postur, keseimbangan. Ketiga, pontocerebellum (neocerebellum); berfungsi untuk keseimbangan tubuh, kecepatan serta ketepatan pergerakan tubuh dan perkataan. Batang otak (brainstem), posisinya berada didalam tulang tengkorak bagian dasar dan memanjang sampai ke tulang punggung atau sumsum tulang belakang. Batang otak tersusun atas otak tengah, pons, dan medulla. Didalamnya terdapat inti syaraf kranial dan jalan naik-turunnya pertukaran informasi dari otak, otak kecil, dan tulang belakang. Bagian otak ini mengatur fungsi dasar kehidupan seperti pernafasan, denyut jantung, suhu tubuh, proses pencernaan, dan lain-lain.

Otak Laki-Laki Dan Perempuan Serta Karakteristiknya, Laki-laki dan Perempuan secara mendasar manusia diciptakan dalam dua tipe berbeda yang memiliki esensi yang berbeda. Kita melabelinya dengan "laki-laki dan perempuan". Perbedaan itu adalah sunnatullah yang diciptakan dengan tanpa mendiskreditkan atau mendeligitimasi tipe yang lain. Perbedaan esensi tersebut diciptakan guna saling melengkapi. Secara umum, setidaknya terdapat tiga titik perbedaan antara laki-laki dan perempuan yaitu: struktur otak, organ reproduksi, dan cara berpikir. Secara biologis, tipe manusia terbagi menjadi jenis kelamin (seks), bukan gender, yaitu laki-laki dan perempuan. Jenis kelamin adalah struktur biologis (alat kelamin, hormon reproduksi, anatomi-fisiologi tubuh, dsb), sedangkan gender adalah sebuah konsep tentang peran sosial laki-laki dan perempuan. Pemaknaan komprehensif tentang hal ini disampaikan oleh Dr. Alexis Carrell, peraih nodel kedokteran 1912, ia menyatakan, perbedaan yang ada pada laki-laki dan perempuan tidak datang dari ke-khas-an bentuk organ reproduksi masingmasing, juga karena adanya rahim dan kandungan wanita atau juga metodologi pendidikan. Perbedaan itu muncul dari pembentukan struktur tubuh itu sendiri, juga dari prosesn pembuahan tubuh dari bahan kimia yang dihasilkan oleh indung telur. Pernyataan tersebut diperkuat oleh Mellisa Hines, dari Universitas California di San Diego ia menyatakan bahwa memang "dari sana-nya" perempuan dan laki-laki berbeda. Mereka diperbedakan sejak masih dalam kandungan. Bahkan, ketika masih berbentuk sel-sel kecil dalam kandungan. Dalam setiap selnya akan terkandung tipologi jenis kelaminnya, yang akan mempengaruhi organ-organ tubuhnya, sistem syarafnya, dan perilaku hidupnya. Esensi ini yang sering tidak dipahami oleh aktivis pro-feminisme. Maka seharusnya setiap individu tumbuh dan berkembang, mengembangkan dan meningkatkan kapabilitasnya sesuai dengan tipologinya tanpa harus meminta dirinya disamakan dengan tipe (pria-wanita) yang lain. Dengan cara itulah mereka akan mendapati keluhuran dirinya yang sesungguhnya.

Otak Laki-laki dan Perempuan, Pemahaman perbedaan biologis laki-laki dan perempuan akan lebih mendalam dengan memahami struktur otak manusia. Terkait hal itu, Pasiak (2005: 91) mengemukakan bahwa struktur otak laki-laki dan perempuan memiliki perbedaan pada (1) corpus calossum (2) hypothalamus (3) inferior parietal lobe (lobus parietal bawah) (4) hippocampus. Perbedaan anatomi tersebut akan berimplikasi pada perbedaan cara dan gaya melakukan sesuatu termasuk belajar. Secara umum ukuran otak berbeda antara laki-laki dan 
perempuan. Laki-laki memiliki ukuran otak lebih besar dari perempuan. Berikut data rerata berat otak laki-laki dan perempuan.

Dalam proses perkembangannya pun otak pada laki-laki dan perempuan tidak mengikuti pola yang sama. Secara umum pada laki-laki yang berkembang terlebih dulu adalah otak kanan kemudian otak kiri. Namun pada perempuan perkembangan otaknya lebih berimbang antara otak kiri dan kanan. Pada usia 0-6 tahun, perempuan otak kanan dan kirinya berkembang dengan kecepatan yang berimbang. Sedangkan pada laki-laki yang dominan berkembang adalah otak kanannya. Sehingga, kita banyak mendapati pada usia sekolah siswa yang pintar dan berprestasi (pandai membaca, menulis, juara kelas, dsb) didominasi oleh siswa perempuan. Hal ini pula yang menjadi pemicu siswa laki-laki banyak yang nakal dan suka membuat ulah. Memasuki usia $6-12$ tahun, otak laki-laki mulai berkembang secara berimbang antara otak kiri dan kanan, dan ketika memasuki usia 18 tahun (dewasa) kecepatan perkembangan otak kiri dan kanan pada laki-laki sudah sempurna. Pada usia inilah, jati diri lakilaki-nya mulai terlihat dimana mereka mulai bisa membuat kerangka kerja dan pencapaian, membuat gambaran masa depan, menjadi pemimpin (BEM, UKM, organisasi, dsb), menyampaikan gagasan, berkomunikasi (orasi, diskusi, dsb). Bersamaan dengan itu, perbedaan hormon juga makin memperkuat ekspresi perkembangan otak laki-laki dan perempuan. Hormon testosteron pada laki-laki membuat mereka senang akan tantangan, suka bersaing, beradu gagasan dan konsep, sehingga mereka senang (betah) berdiskusi atau rapat. Perempuan juga senang berkumpul, namun karena hormon yang dimilikinya didominasi oleh estrogen dan progesteron, membuat mereka lebih memilih damai, santai, dan seterusnya sehingga ketika mereka berkumpul, yang mereka nikmati adalah "berkumpulnya" bukan materi atau substansi berkumpul karena ketika berkumpul mereka mengumpulkan informasi. Kondisi ini juga mempengaruhi pilihan aktifitas dan posisi yang dijalani. Umumnya pada level ini, perempuan akan lebih banyak menekuni aktifitas yang sejalan dengan fitrahnya seperti sekretaris, bendahara, seksi konsumsi, dan sejenisnya.

Corpus Calossum adalah sebuah materi putih yang terdiri atas serat yang menghubungkan materi putih dari dua belahan otak. Fungsi utamanya ialah memfasilitasi koordinasi, komunikasi, dan pertukaran informasi antar belahan otak kiri dan kanan. Sandra F. Witelson, profesor neurosains di Mc Master University, dalam penelitiaannya menemukan bahwa corpus calossum perempuan berukuran lebih tebal $\pm 30 \%$ dari laki-laki. Tebalnya tersebut dominan berada di area keterampilan linguistik (isthmus dan splenium). Kondisi ini menjadikan setiap bagian otak laki-laki akan bekerja secara terpisah, sehingga mereka lebih cepat untuk konsentrasi dan fokus pada apa yang dikerjakannya saat itu, tapi di saat bersamaan tanpa disadari pendengarannya akan menurun. Sedangkan perempuan, karena struktur yang lebih tebal ini memungkinkan otak bisa bekerja secara bersamaan, dan menjadikan mereka multitasking, mampu mengerjakan dua atau lebih pekerjaan yang tidak berhubungan sama sekali pada waktu yang bersamaan. Dalam berbahasa, corpus calossum yang lebih tebal menjadikan perempuan ketika berbicara bisa lebih lancar dan tidak terbatas dalam makna tidak fokus atau terpaku pada satu topik pembicaraan. Secara anatomis juga terbukti bahwa pusat bahasa pada otak perempuan penyebarannya pada kedua belahan otak jauh berbeda dari pada otak laki-laki. Tidak heran perempuan lebih punya kemampuan berkomunikasi dibanding laki-laki baik melalui kata-kata, nada suara, empati, atau gestur tubuh. Menurut dr. Aisyah Dahlan, laki-laki berbicara rata-rata 7000 kata, sedangkan perempuan 20.000 kata setiap hari.

Hypothalamus merupakan sebuah struktur yang terletak dibawah thalamus dan tepat berada diatas batang otak. Hipotalamus merupakan bagian otak yang mengeluarkan hormon yang digunakan untuk mengendalikan organ dan sel-sel tubuh. Walau ukurannya kecil, hipotalamus memiliki fungsi sangat penting. Fungsi utamanya adalah memastikan dan mempertahankan sistem tubuh berjalan dengan baik (homestasis). Beberapa fungsi spesifiknya antara lain respons terhadap berbagai stimulus, mengatur sistem endokrin (hormonal), mengontrol sistem saraf otonom seperti regulasi suhu tubuh, mengatur asupan makanan, udara dan rasa haus, mengontrol siklus harian dan perilaku fisiologis, mengontrol respons emosi, dan fungsi-fungsi kunci lainnya seperti pengaturan perilaku yang terkait dg eksistensi hidup (berkelahi, makan, melarikan diri, seksualitas dan reproduksi, dsb). Secara umum hipotalamus laki-laki terutama pada preoptic region berukuran 2,5 - 3 kali besar dari perempuan. Kondisi ini menjadikan laki-laki memiliki tingkat kepekaan terhadap stimulus yang lebih tinggi dari perempuan termasuk juga dalam hal berkait dengan seks. Laki-laki lebih peka terhadap stimulus (suara, sentuhan, dst) daripada emosi, perempuan sebaliknya. Selain itu, otak 
perempuan mengandung hormon serotonin yang lebih banyak, yang juga membuatnya menjadi lebih tenang.

Inferior Parietal Lobe, la adalah salah satu dari tiga divisi dari lobus parietalis.Terdiri dari supramarginal gyrus dan angular gyrus. Struktur ini bertanggung jawab terhadap kemampuan spasial. Area ini mengatur kemampuan visuo-spasial dan sangat perlu untuk hal-hal yang berkaitan dengan matematika dan arsitektur. Hasil pengujian MRI menunjukkan bahwa inferior parietal lobe pada laki-laki lebih besar $6 \%$ dibandingkan perempuan. Selain itu inferior parietal lobe pada perempuan terlihat asimetris antara lobus kiri dan kanan. Kemampuan untuk membayangkan (imaging) dan membangun model imajiner tiga dimensi dari sebuah gerakan, posisi dan lainnya berkembang lebih baik pada laki-laki dibanding perempuan. Hal itu berwujud dalam kemampuan perancangan mekanis, pengukuran penentuan arah abstraksi, dan manipulasi benda-benda fisik. Tidak heran banyak laki-laki yang senang mengutak-atik atau modifikasi suatu barang.

Hippocampus merupakan bagian dari sistem limbik yang terletak di lobus temporal medial otak. Bagian otak ini terdiri dari beberapa struktur kunci yaitu hippocampus proper, alveus, dan subiculum. Area ini bertanggung jawab atas ingatan (memori) baik jangka panjang atau jangka pendek, dan juga berperan dalam pembentukan memori navigasi serta spasial. Pusat memori (hippocampus) pada otak perempuan lebih besar ketimbang pada otak pria. Oleh sebab itu, perempuan mampu mengingat sesuatu lebih lama bahkan sampai pada detilnya. Kondisi ini pula yang menyebabkan laki-laki mudah lupa. Inilah yang menyebabkan laki-laki lebih mudah move-on dari sebuah trauma dibandingkan perempuan. Namun demikian dalam perkembangannya, sel-sel hippocampus dan juga sel lobus parietal pada perempuan lebih cepat menghilang (mati), sehingga perempuan pada saat tua akan lebih mudah kehilangan memori, kemampuan pengenalan spasial, dan juga menjadi pelupa.

Perbedaan otak dan cara belajar, Tidak boleh kita ingkari bahwa otak seorang anak lakilaki dan perempuan sangat berbeda. Kondisi demikian pasti menjadikan cara dan gaya belajar mereka juga berbeda. Perbedaan tersebut harus menjadi pertimbangan bagi orang tua dan pendidik dalam memberikan pengajaran yang berkesesuaian pada siswa dan anak. Michael Guriaan, penulis buku Boys and Girls Learn Differentially menyatakan perbedaan otak ini harus menyadarkan kita bahwa struktur otak yang berbeda sangat berperan pada pola belajar dan cara kerja otak mereka, walaupun tidak mutlak. Mengacu pada fase perkembangan dan perbedaan struktur otak, anak laki-laki lebih senang belajar memahami konsep dengan melihat gambar, grafik, atau belajar melalui aktifitas hands-on seperti praktik, merangkai, mendesain, membuat simulasi, dan sebagainya yang menjadikan tubuh mereka bergerak karena pada level usia sekolah mereka masih lebih banyak menggunakan otak kanannya untuk memahami sesuatu. Sementara anak perempuan untuk mempelajari sebuah konsep mereka lebih nyaman melalui membaca, menulis, bekerjama (berdiskusi) dengan teman, atau melalui pola komunikasi lainnya seperti drama atau teatrikal karena memang kemampuan bahasa mereka matang lebih cepat dan kapasitasnya lebih besar dibandingkan laki-laki. Namun pada level pendidikan menengah dan tinggi, siswa laki-laki dalam belajar sesuatu atau menyelesaikan suatu masalah mereka akan lebih senang ketika mendapati sesuatu yang baru atau menantang apalgi yang sifatnya menuntut mereka harus hands-on. Perilaku ini muncul sebagai efek dari kinerja otak kirinya yang baik dan juga dipengaruhi oleh hormon testosteron dalam dirinya. Oleh karena itu, pendidik harus selalu menyiapkan pola penyajian materi yang senantiasa membuat mereka tertantang, baik dengan cara meminta mereka membuat simulasi, membuat kompetisi, debat, dan sebagainya. Tidak demikian halnya dengan anak perempuan. Mereka akan menikmati proses belajar dan bisa memahami tentang sesuatu atau menyelesaikan suatu masalah dengan cara-cara yang mengedepankan komunikasi yang sifatnya "persuasif" dan komunal dengan belajar bersama, membaca, diskusi santai, merumuskan pemahaman bersama, presentasi, ceramah, dan sebagainya.

Dalam proses belajar, seringkali siswa laki-laki cuek, tidak memperhatikan, tidak tenang, namun sesungguhnya mereka mendengarkan dengan seksama dan mengolah informasi yang disampaikan guru. Ketika dia melakukan suatu kekeliruan, siswa laki-laki akan lebih mudah mengenalinya melalui stimulus (suara, teguran, atau sentuhan ketimbang ekspresi emosi. Hal ini disebabkan karena struktur hipotalamusnya yang lebih besar dari perempuan. Siswa perempuan lebih mudah ditegur, cukup dengan memunculkan ekspresi seperti melotot, menggelengkan kepala, dan sebagainya. Karena kemampuan hafalannya yang tinggi, siswa perempuan juga cenderung lebih suka belajar dan bisa mempelajari sesuatu dengan cara yang mengedepankan komunikasi (berbicara, menulis, diskusi, dsb), sedangkan anak laki-laki karena hafalannya tidak seperti perempuan, mereka senang dan harus belajar dengan pola yang 
mampu membangun struktur imajiner konsep dalam pikiran mereka melalui praktikum, aktifitas hands-on, membuat desain objek, dan sebagainya, tidak cukup hanya dengan membaca, diskusi, layaknya siswa perempuan.

\section{Implikasi dalam pendidikan}

Seperti dikemukakan diawal bahwa pendidikan bertujuan untuk memanusiakan manusia. Maka proses pendidikan harus dijalankan sesuai dengan karakteristik manusia itu sendiri. Dalam paparan sebelumnya sudah bahwa perbedaan struktur otak laki-laki dan perempuan mengharuskan pula adanya pola pendidikan yang berbeda. Secara aksiologi, pemahaman terhadap perbedaan struktur otak laki-laki dan perempuan akan memberikan kita landasan untuk melakukan penyesuaian dalam praktik pendidikan yang lebih selaras dengan karakteristik siswa. Beberapa hal yang bisa ditempuh diantaranya: (1) Pada level pendidikan dasar yang mengajar harus lebih banyak guru perempuan, karena guru perempuan lebih sabar dan lebih bersahabat ketika menghadapi siswa, sedangkan untuk sekolah menengah bisa diperbanyak guru laki-laki atau berimbang, (2) Memisahkan siswa dalam kelas laki-laki dan kelas perempuan, sehingga mereka lebih mudah belajar sesuai karakternya, (3) Menyiapkan guru laki-laki untuk kelas laki-laki, dan sebaliknya. (4) Jika kelas tetap menyatu antara laki-laki dan perempuan, maka guru harus mengajar dengan cara kombinasi, guna memfasilitasi perbedaan cara belajar siswa laki-laki dan perempuan, (5) Otak akan optimal menyerap informasi ketika dalam keadaan relaks (tenang), maka sebelum pembelajaran dimulai, siswa harus diajak melakukan aktifitas relaksasi baik berdzikir, refleksi diri, dan sebagainya. Penelitian ini didukung oleh penelitian Arniati (2015) yang mengatakan pembelajaran neurosains dikombinasikan dengan berbagai disiplin ilmu sehingga terintegrasi dan menjadi arus utama pembentukan karakter.

\section{Simpulan}

Peran otak tidak bisa dikesampingkan dalam proses kehidupan individu. Setiap individu akan berkembang mengikuti karakteristik biologisnya termasuk otak. Jenis kelamin yang berbeda ternyata juga memunculkan karakter otak yang berbeda. Maka didalam setiap individu yang berbeda kelamin tersebut tersimpan potensi yang juga berbeda. Potensi tersebut harus bisa dioptimalkan dengan proses pendidikan yang sesuai. Struktur otak laki-laki dan perempuan yang berbeda, menghasilkan cara dan gaya belajar yang berbeda. Laki-laki lebih mudah mempelajari sesuatu dengan cara yang mengedepankan aktifitas hands-on seperti praktikum, desain, merangkai alat, dan sebagainya, dan minim komunikasi (verbal dan non-verbal). Sedangkan perempuan, lebih senang belajar dengan cara dan gaya yang berkaitan dengan komunikasi seperti ceramah, berbicara, menulis, diskusi santai, atau presentasi.

\section{Daftar Pustaka}

Dekaban, A.S. \& Sadowsky, D. (1978). Changes in Brain Weights During The Span of Human Life: Relation of Brain Weight to Body Heights and Body Weights. Journal of Neurology, Vol. 4: 345-356.

Erniati. 2015. Pembelajaran Neurosains Dalam Pembentukan Karakter Peserta Didik Pada Pondok Pesantren. Hunafa: Jurnal Studia Islamika Vol. 12, No. 1, Juni hal 43-69.

Hewitt, Paul \& Lyons, Suzanne \& Suchocki, John \& Yeh, Jennifer. (2007). Conceptual Integrated Science. San Fransisco: Pearson Education Inc.

Pasiak, Taufik. (2004). Revolusi IQ/EQ/SQ: Antara Neurosains dan al-Qur'an. Bandung: Mizan Pustaka

Rakhmat, Jalaluddin. 2005. Belajar Cerdas Belajar Berbasiskan Otak. Bandung: MLC

Rohkamm, Reinhard. (2004). Color Atlas of Neurology. Stuttgart: Georg Thieme Verlag

Silberman, I. 2005. Religion as a meaning system: Implications for the new millennium. Journal of Social Issues Vol. 2 No . 4.

Suyadi, 2012. "Model Pendidikan Karakter dalam Konteks Neurosains", Proceeding Seminar Nasional, Yogyakarta: Prodi PGMI Fakultas Tarbiyah UIN Sunan Kalijaga.

Tafsir, Ahmad. 2006. Filsafat Pendidikan Islami, Integrasi Jasmani, Rohani dan Kalbu, Memanusiakan Manusia. Bandung: Remaja Rosda Karya,

Wathon, Aminul. 2016. Neurosains Dalam Pendidikan. Jurnal Lentera: Kajian Keagamaan, Keilmuan dan Teknologi Volume 14, Nomor 1. 